\title{
ОРГАНИЗАЦИОННО-ЭКОНОМИЧЕСКИЙ МЕХАНИЗМ РАЗВИТИЯ ОТРАСЛЕЙ СЕЛЬСКОХОЗЯЙСТВЕННОГО ПРОИЗВОДСТВА
}

\author{
(c) 2020 Мазлоев Виталий Зелимханович \\ доктор экономических наук, профессор, Заслуженный деятель науки РФ, \\ Главный научный сотрудник ВНИОПТУСХ - филиал ФНЦ аграрной экономики \\ и социального развития сельских территорий - ВНИИЭСХ, Россия, Москва
}

Сельское хозяйство как комплексообразующая отрасль агропродовольственного комплекса, представляющего собой базовый элемент общественного воспроизводства, вот уже на протяжении последних почти десятка лет демонстрирует довольно-таки устойчивый рост. Россия вышла в число ведущих государств-экспортеров продовольствия и сельскохозяйственного сырья, вывоз которых увеличился в 1,5 раза, то есть наряду с углеводородами наша страна поставляет на мировой рынок значительную часть продуктов питания, что свидетельствует о достаточно стабильной тенденции развития отечественного аграрного сектора.

Однако этого явно недостаточно, чтобы выйти на качественно отличные параметры его функционирования. Для поддержания стабильной результативности необходимо сформировать дееспособный экономический механизм, адекватный объективно существующей общественноэкономической формации.

Ключевые слова: агропродовольственный комплекс, сельскохозяйственное производство, отрасль сельского хозяйства, экономический механизм.

Введение. Принятые в отношении России международные санкции и введенное в нашей стране в качестве ответа продовольственное эмбарго, ограничивающее ввоз целого ряда продовольственных товаров из довольно большого количества стран, предоставило отечественному аграрному сектору уникальную возможность для наращивания производства и занятия освободившейся ниши на рынке сельскохозяйственной продукции сырья и продуктов питания. Однако ориентация на импортозамещение повлекла за собой определенные негативные последствия, которые в большей степени вызваны не технико-технологическими, а организационноэкономическими, в частности неадекватностью хозяйственного механизма АПК и его составной части экономического механизма, представляющего собой многоаспектную экономическую категорию, обладающую совокупностью рычагов и методов воздействия на экономические процессы. Вариабельность экономического механизма обусловленная уровнем развития производительных сил и производственных отношений, определяет его трансфармационность, которая зачастую имеет достаточно негативные последствия. Так радикальные, непродуманные рыночные реформы 90-х годов ввергли Российское село в глубочайший экономический и соци- альный кризис, который еще перманентно продолжается [9].

Основополагающей идеей и целью проведенного исследования явилась разработка предложений по совершенствованию экономического механизма аграрного сектора. В этом процессе были использованы различные методы научного познания: диалектический, аналитический, расчетно-конструктивный.

В качестве объекта нами был определен агропродовольственный комплекс Владимирской области.

Необходимо увеличить объем государственной поддержки сельского хозяйства Владимирской области из федерального бюджета не менее 3,5 млрд. руб. Это позволит ликвидировать дефицит субсидий и дотаций на реализуемые и планируемые инвестиционные проекты направленные на увеличение объемов производства в растениеводческой отрасли, в т.ч. и за счет расширения посевных площадей под сельскохозяйственные культуры. В настоящее время дефицит в субсидируемых кредитах на реализацию долгосрочных инвестиционных проектов в сельском хозяйстве еще достаточно ощутим, то есть объем субсидий и дотаций выделяемых из федерального и областного бюджета крайне не достаточен. 
В последние годы сельхозтоваропроизводителям области на развитие сельскохозяйственного производства в рамках Госпрограммы выделялось 1417,3 млн. руб., в то числе из средств федерального бюджета - 1028,1 млн. руб., областного - 389,2 млн. руб. При этом задолженность по инвестиционным кредитам составляет около 5 млрд. руб., что говорит о серьезной их нехватке. В настоящее время дефицит в субсидируемых кредитах на реализацию долгосрочных инвестиционных проектов (в том числе по освоению земель) составляет около 15 млрд. руб., то есть объем субсидий и дотаций, выделяемых из бюджетов всех уровней крайне недостаточен.

Корреляционно-регрессивный анализ выявил высокую зависимость объема производства сельскохозяйственной продукции от господдержки АПК Владимирской области (коэффициент детерминации $\mathrm{R} 2=0,87)$. На основании данного анализа составлено уравнение регрессии $\mathrm{y}=\mathrm{a}+\mathrm{b}$ * $\mathrm{x}$ (эмпирическое уравнение регрессии):

$\mathrm{y}=21054,7+7,3 \mathrm{x}$,

где у - продукция сельского хозяйства в фактически действовавших ценах, млн.рублей;

x - господдержка АПК, млн.руб.

Коэффициент регрессии $\mathrm{b}=7,3$ показывает среднее изменение результативного показателя (в единицах измерения у) с повышением или понижением величины фактора $\mathrm{x}$ на единицу его измерения. Этот анализ позволяет сделать вывод о том, что в сельском хозяйстве Владимирской области с увеличением господдержки АПК на 1 млн. руб. объем производства сельскохозяйственной продукции в действующих ценах увеличится в среднем на 7,3 млн. руб.

В этой связи можно составить прогноз на 2020 г. и 2025 г. производства сельскохозяйственной продукции во Владимирской области по двум сценариям:

1-й сценарий: Объем государственной поддержки сохранится на текущем уровне 2017 года и составит 1070 млн. руб. Соответственно объем производства сельскохозяйственной продукции в действующих ценах в 2020 году будет составлять - 24,6 млрд. руб., в 2025 году - 29,5 млрд. руб.

2-й сценарий: Государственная поддержка ежегодно будет увеличиваться на 5\% по отношению к уровню 2017 года и составит в 2020 году $-1,17$ млрд. руб., в 2025 году - 1,5 млрд. руб. Соответственно объем производства сельскохозяйственной продукции в действующих ценах в 2020 году достигнет - 27,7 млрд. руб., в 2025 году - 31,2 млрд. руб.

Необходимо возобновить, хотя бы на уровне региона, товарно-специфические субсидии (на единицу площади, единицу продукции), при этом осуществлять такое субсидирование дифференцированно по видам продукции (масличные, энергонасыщенные кормовые и т.д.), а также жестко контролировать фактические размеры посевных площадей.

Повышение эффективности использования потенциала аграрного сектора Владимирской области, который в основном сосредоточен в крупных сельхозорганизациях, позволит увеличить объем производства сельскохозяйственной продукции к 2025 году в 2,5-3 раза (расчет произведен к данным сельского хозяйства в 19901991 гг.)

В 2018 году объем производства сельхозпродукции в действующих ценах на сумму 33,1 млрд. руб., что составляет 6,6\% ВРП. Основными производителями продукции сельского хозяйства являются сельскохозяйственные организации, на долю которых приходится 61,7\% всего объема производимой сельхозпродукции Владимирской области.

В целях развития крупнотоварного производства необходимо создать новые сельскохозяйственные организации или возобновить работу ранее действующих (используя комплекс антикризисных мер), в т.ч. на неиспользуемых и заброшенных сельхозугодиях.

Следует временно освободить от налогообложения, в частности от земельного налога на вновь осваиваемые, выведенные из оборота земли, в том числе инвесторов, так как по нашим расчетам затраты на восстановление одного гектара пашни составит 100-130 тыс. руб.

Наряду с крупнотоварным производством в сельском хозяйстве региона есть и малые формы хозяйствования, правда производимая ими продукция составляет всего лишь 3,3\% от общего объема производимой сельхозпродукции в области.

В соответствии с условиями подпрограммы «Поддержка малых форм хозяйствования» Постановления Губернатора Владимирской области «Об утверждении Государственной программы развития агропромышленного комплекса Владимирской области на 2013-2020 годы» объем ассигнований из всех источников составит 19738209,8 тыс. руб., включая бюджеты феде- 
ральный и областной и довести удельный вес их продукции к 2025 году до 38\% (средний показатель по РФ).

Однако фермеры и тем более личные подсобные хозяйства зачастую не имеют возможности развиваться за счет участия в крупных инвестиционных проектах и даже в программных мероприятиях.

С целью ликвидации такой негативной ситуации предлагается следующий организационноэкономический механизм взаимодействия крупного и малого агробизнеса:

- инвестор возводит на территории определенного хозяйствующего субъекта строит и вводит в эксплуатацию объект (ферма, пункт забоя и т.д.);

- сельхозтоваропроизводитель (фермер) заготавливает корма и другие работы;

- финансовый институт под залог этого объекта финансирует от $50 \%$ до $70 \%$ фактической его стоимости;

- возможно частичное финансирование из средств областных программ и региональных СПК;

- в качестве залогового покрытия можно применить будущие субсидии на основании соглашения с регионом;

- инвестор может рассмотреть на определенный процент гарантирования сделки.

Необходимо на основании существующих ЛПХ создавать фермерские хозяйства, тем самым после создания КФХ, они смогут максимально участвовать в государственных программах поддержки сельского хозяйства, малых форм хозяйствования, получать льготные кредиты, гранты и другие формы поддержки как по линии Министерства сельского хозяйства России, Департамента сельского хозяйства и продовольствия Владимирской области.

Кроме того следует провести институциональные преобразования по следующим направлениям:

- развитие кооперативных форм как в области производства сельскохозяйственной продукции, так и в связанных с ним сферах деятельности;

- формирование вертикально-интегрированных кооперативных объединений;

- формирование интегрированных территориальных аграрных кластеров.

Актуальнейшей задачей отрасли земледелия на сегодняшний день является увеличение уровня использования пашни и площади посевов сельскохозяйственных культур в 2 раза, тем самым повысить объем производства сельскохозяйственной продукции. Такое предложение основано на том, что в настоящее время во Владимирской области из сельскохозяйственного оборота выведено 229 тыс. га, что составляет 40\% всей пашни, из этих земель 139 тыс. га не используются более 10 лет. Однако темпы вовлечения земель в оборот очень низки (около 7 тыс. га). Это огромный потенциал для развития аграрного сектора региона, позволяющий увеличить производство сельхозкультур, расширить кормовую базу ведущей отрасли - животноводства.

Безусловно, восстановление выведенных из оборота земель потребует вложения очень больших средств, не менее 100 тыс. в среднем на один гектар пашни, поэтому необходимо принятия мер на федеральном уровне (финансовая поддержка этих мероприятий, принятия законодательных и нормативно-правовых актов), которые бы оказали стимулирующее воздействие на привлечение частных инвестиций, учитывая очень выгодное географическое расположение области.

В числе таких мер налоговые льготы для бизнеса, осваивающего неиспользуемые земли, аналогичное кредитование в том числе для создания материально-технической базы через систему агролизинга, так как проведение работ потребует приобретения мощной техники для выкорчевывания образовавшихся лесных массивов.

С целью поддержки и сохранения плодородия почвы площади под зерновые культуры должны быть заметно сокращены, переориентированы внутри региона и введены эффективные севообороты, расширен объем паровых земель. Но все это нужно делать без снижения, и даже при увеличении объема выращиваемых зерновых за счет повышения урожайности. На сегодняшний день средняя урожайность зерновых по области 20,9 ц/га, а в передовых хозяйствах Собинского, Суздальского и Юрьев-Польского районов достигает 26-29 ц/га. Стало быть, следует пересмотреть специализацию и размещение сельскохозяйственного производства внутри региона.

Используя опыт передовых хозяйств области и рекомендации ученых по значительному увеличению производства элитных семян и 
расширению семеноводческих хозяйств, а также улучшению агротехники можно было поставить задачу поднять урожайность до 30 центнеров с 1 га к 2025 году, что обеспечит при определенном сокращении посевных площадей под зерно увеличение валовых сборов.

В общей структуре экспорта сельскохозяйственной продукции Владимирской области возможно повысить более дорогой экспорт с единицы посевной площади семян льна до 10\% всего экспорта, семян подсолнечника - до $4 \%$ экспорта, семян рапса - до 5\% экспорта.

Что касается кормовых культур, то здесь для повышения продуктивности скота, прежде всего, молочного, крайне важно значительно увеличить, удвоить, а, может быть, и утроить посевы кукурузы на силос и продуктивных многолетних трав, например, люцерны.

Для значительного расширения посевов масличных и кормовых культур следовало бы возобновить отмененное погектарное стимулирование развитием масличных культур и поощрять развитие кормовой базы, учитывая при этом, что расширение посевов кормовых культур в севообороте будет содействовать повышению уро- жайности зерновых. Нужно при этом учесть, что рентабельность производства масличных культур ниже, чем производство зерновых культур. Но стоимостной объем производства в расчете на 1 гектар посевов масличных культур больше.

На сегодняшний день важнейшей задачей аграрного сектора региона является повышение продуктивности и устойчивости сельскохозяйственного производства и плодородия почв средствами комплексной мелиорации в условиях изменения климата и природных аномалий, повышение продукционного потенциала мелиорируемых земель и эффективного использования земельных ресурсов.

По состоянию на 01.01.2018 года в области не используется 229,0 тыс. га земель (40\% от наличия пашни), из них 139,0 тыс. га не используются более 10 лет.

Активизация деятельности по возвращению неиспользуемых земель в сельскохозяйственный оборот необходима для наращивания объемов производства растениеводческой продукции, удовлетворение потребностей населения в продовольственных ресурсах и в целях импортозамещения.

\section{Библиографический список}

1. Государственная программа развития сельского хозяйства и регулирования рынков сельскохозяйственной продукции, сырья и продовольствия на 2013-2020 гг. Постановление Правительства РФ № 717 от 14.07.2012 г.

2. о развитии сельского хозяйства: Федеральный закон № 264 от 29 декабря 2006 г.

3. Об утверждении доктрины продовольственной безопасности Российской Федерации: Указ Президента РФ № 120 от 30 января 2010 г / Собрание Законодательств Российской Федерации. М.,2010. № 5. с. 502. С. 652659.

4. Буздалов И. Н. Хозяйственный механизм в агропромышленной сфере стран СЭВ / И. Н. Буздалов - М.: Наука. 1988. с.303.

5. Мазлоев В.З. Адаптация хозяйственного механизма к санкционным мерам / В.З. Мазлоев // Экономика сельскохозяйственных и перерабатывающих предприятий. 2015.№ 3. С. 13-18.

6. Мазлоев В.3. Механизм государственной поддержки: стимулы и ограничения в системе распределения субсидий. / В. З. Мазлоев, А.Б. Кцоев // Экономика сельскохозяйственных и перерабатывающих предприятий. 2011 № 9. С. 16-22.

7. Мазлоев В.З.Организационно-экономический механизм реализации стратегий экономического роста. / В. З. Мазлоев, Ю. В. Лысенко, М. В. Лысенко; под ред. А. Н. Семина. Челябинск: Печатный двор. 2011. 442 с.

8. Мазлоев В.З. Оценка возможностей субсидирования отечественных сельхозтоваропроизводителей в условиях членства России в ВТО / В.З. Мазлоев, А. В.Приемко // Экономика сельскохозяйственных и перерабатывающих предприятий. 2012. № 7. С. 30-33

9. Мазлоев В.З., Озерова М. Г. Современные проблемы развития экономического механизма аграрного сектора. Красноярск. 2018. 258c. 